\title{
Manometric measurements of temperature influence on Anammox activity
}

\author{
Maciej Leoniak ${ }^{1}$, and Piotr Balbierz ${ }^{1, *}$ \\ ${ }^{1}$ Wroclaw University of Science and Technology, Faculty of Environmental Engineering, Wybrzeze \\ Wyspianskiego27, 50-370 Wroclaw, Poland
}

\begin{abstract}
Wastewater treatment plants face more stringent effluent limits, especially with regard to total nitrogen, which force them to consider sidestream nitrogen removal from digested sludge dewatering liquor which can contain up to $20 \%$ of incoming nitrogen load. One of the most promising technologies for sidestream nitrogen removal is the deammonification process which is based on partial short-cut nitrification and the Anammox process. Anammox process is an anaerobic ammonia oxidation with nitrite conducted by slowly growing autotrophic bacteria. Ensuring adequate activity of sensitive Anammox bacteria is a key condition for effective deammonification. As the main product of Anammox bacteria is the nitrogen gas, the assessment of Anammox activity can be based on manometric measurements which are a relatively simple and cost-effective alternative to traditional tests involving determination of soluble nitrogen forms. This paper presents the principles of manometric method as well as results of temperature influence on Anammox activity obtained in a commercially available lab-scale set-up.
\end{abstract}

\section{Introduction}

The potential existence of chemolithotrophic bacteria anaerobically oxidizing ammonia with nitrite/nitrate to dinitrogen gas was predicted, based on the theoretical thermodynamic calculations, already in the 1970s. However, it was not until 1990s, that the effects of such a process were observed in reality, first in the technical systems, and later widespread in the natural environment. Later it was discovered that this process is important at global scale as it considerably affects the global nitrogen cycle, especially in the oceans, where it outcompetes denitrification $[1,2]$.

The bacteria responsible for this process, usually called anammox bacteria (abbreviation for ANaerobic AMMonium OXidation), belong to the order of Planctomycetes, and three candidate genera has been identified so far, including Candidatus Brocadia, Candidatus Kuenenia and Candidatus Scalindua. Different species rarely exist together, suggesting different requirements and optimal conditions for growth $[1,2]$.

In engineering practice anammox process becomes more commonly applied as wastewater treatment plants face more stringent effluent limits, especially with regard to

${ }^{*}$ Corresponding author: piotr.balbierz@pwr.edu.pl 
total nitrogen, which force them to consider sidestream nitrogen removal from digested sludge dewatering liquor which can contain up to $20 \%$ of incoming nitrogen load [3].

The most innovative and promising biological technology for sidestream nitrogen removal is deammonification which is based on partial short-cut nitrification and the anammox process [4]. As raw reject water contains mainly ammonium, the partial nitrification step, conducted by strictly aerobic ammonium oxidizing bacteria, is required to oxidize approximately half of the initial ammonium to nitrite. In the anammox step ammonium (electron donor) and nitrite (electron acceptor) are converted by strictly anaerobic anammox bacteria into dinitrogen gas and small amounts $(\sim 10 \%)$ of nitrate without external organic carbon source, according to equation $[3,5]$ :

$$
\begin{aligned}
\mathrm{NH}_{4}^{+}+1.32 \mathrm{NO}_{2}^{-}+0.066 \mathrm{HCO}_{3}^{-}+0.13 \mathrm{H}^{+} \rightarrow \\
\quad \rightarrow 1.02 \mathrm{~N}_{2}+0.256 \mathrm{NO}_{3}^{-}+0.066 \mathrm{CH}_{2} \mathrm{O}_{0.5} \mathrm{~N}_{0.15}+2.03 \mathrm{H}_{2} \mathrm{O}
\end{aligned}
$$

The advantage of deammonification is that it allows to decrease oxygen demand by $60 \%$, and organic carbon demand and sludge production by $90 \%$, compared to conventional nitrification/denitrification systems $[1,3,5]$.

In full-scale installations, deammonification is usually operated as a one-stage system, where both steps with different requirements take place in one reactor, which results in higher volumetric efficiency and lower investment costs, but makes the process control more complicated. An alternative are two-stage systems, where partial nitritation and anammox are split in two reactors in series, which allows to optimize process condition for each of the steps separately [3].

The weakness of deammonification is that both steps, and especially anammox, are conducted by extremely slowly growing autotrophic bacteria with a long doubling time of 11 days [6]. This means that in case of washout or toxicity incidents, the recovery of the system will take a long time, during which the untreated reject water will increase the loading of the mainstream system. Therefore, it is crucial to operate the deammonification installations at optimum conditions (temperature, $\mathrm{pH}$, substrate ratio) to support the maximum growth rate of anammox bacteria [7].

\subsection{Temperature effect on Anammox activity}

Temperature is one of the most important factors affecting microbial growth in general, and biological wastewater treatment in particular. In engineering applications, the temperature dependency of biological processes is usually expressed using the following equation [7]:

$$
\mu_{T}=\mu_{T_{r}} \theta^{\left(T-T_{r}\right)}
$$

where $\mu_{T}$ and $\mu_{T r}$ are the maximum specific growth rate at process temperature $T$ and reference temperature $T_{r}$, respectively, and $\theta$ is the temperature correction factor.

It has been generally reported that the optimum temperature for growth of anammox bacteria was in the range of $30-40^{\circ} \mathrm{C}$ [8], whereas other authors claimed to observe the highest activity even at $43^{\circ} \mathrm{C}$ [7]. Therefore, most of up to date anammox applications were on warm $\left(\mathrm{T}>30^{\circ} \mathrm{C}\right)$ and high strength $(>0.1 \mathrm{~g} \mathrm{~N} / \mathrm{L})$ streams, mostly reject water from digested sludge dewatering. Moreover it was shown that temperature decline leads to severe anammox activity suppression [9].

However, recently it was proved that successful anammox operation at temperatures around $20^{\circ} \mathrm{C}$ is possible, especially with immobilized biomass [10, 11]. Moreover, works 
conducted on marine anammox samples from cold regions reported significant activity even at temperatures below $10^{\circ} \mathrm{C}[5]$.

On the other hand, the upper limit for the anammox operation has been reported in the range of $45-55^{\circ} \mathrm{C}$, where significant irreversible loss of activity due to biomass lysis was observed $[5,7]$.

Recently, Lotti et al. [12] and Sobotka et al. [7] showed results suggesting that, contrary to other biological process, the temperature dependency of anammox activity cannot be expressed by a single Arrhenius coefficient, as the temperature induced decline in activity is stronger at lower temperatures. Both studies concluded that for the higher temperature range $\left(15-40^{\circ} \mathrm{C}\right)$ single characteristics can be assumed with temperature coefficient $\theta$ of 1.07 and a corresponding activation energy of $51-66 \mathrm{~kJ} \mathrm{~mol}^{-1}$, which is close to value of $70 \mathrm{~kJ} \mathrm{~mol}^{-1}$ postulated by Strous et al. [13]. Whereas in the low temperature range $\left(10-15^{\circ} \mathrm{C}\right)$ a much higher temperature coefficient $\theta$ of 1.65 and a corresponding activation energy of $231-437 \mathrm{~kJ} \mathrm{~mol}^{-1}$ was determined.

Moreover, Sobotka et al. [7] observed a change in the molar conversion ratio of substrates $\mathrm{NO}_{2}-\mathrm{N} / \mathrm{NH}_{4}-\mathrm{N}$, which in the temperature range $15-30^{\circ} \mathrm{C}$ was close to a typical value of 1.3 , but decreased to a value of 1.0 below $15^{\circ} \mathrm{C}$ - this suggests a significant change in the anammox metabolism at low temperature.

Additional factor that needs to be considered is the potential adaptation of anammox bacteria to lower temperatures. Long term studies showed that adapted anammox biomass has a higher specific rate at lower temperatures, but the extent of adaptation is difficult to predict and likely to depend on the duration of operation [12, 14]. Some researchers suggested that complete adaptation may take months or even years of operation [15].

Therefore, the influence of temperature change on anammox activity, especially in the lower temperature range, and the ability of anammox bacteria to adapt to lower temperatures is still a valid scientific question.

The aim of this study was to determine the short-term influence of temperature on the activity of anammox biomass cultivated at relatively low temperature $\left(23^{\circ} \mathrm{C}\right)$ using manometric measurements in batch tests, in order to estimate the values of temperature coefficient and activation energy.

\section{Materials and methods}

This study was conducted at the pilot plant used for assessment of different reject water treatment processes, equipped with four $150 \mathrm{dm}^{3}$ SBR-type reactors and fed with real reject water from full-scale sludge dewatering station at Wroclaw WWTP in south-west Poland.

Sludge samples were taken from a pilot-scale Anammox SBR fed with partially nitrified real sludge dewatering reject water and operated at temperature of $23^{\circ} \mathrm{C}, \mathrm{pH} 7.0$, an SRT of $50 \mathrm{~d}$ and MLSS of $2.0 \mathrm{~kg} \mathrm{TSS} \mathrm{m}^{-3}$. At start-up this SBR was seeded with granular sludge from an upflow sludge blanket Anammox reactor, and operated in stable conditions for 180 days at the volumetric loading of $>0.7 \mathrm{~g} \mathrm{~N} \mathrm{~L}^{-1} \mathrm{~d}^{-1}$ with treatment efficiency of $>85 \%$.

As the main product of the anammox reaction (Eq. 1) is the poorly soluble nitrogen gas, manometric measurements may be applied to track the rate of the process as it is proportional to the pressure increase rate in a gas-tight reactor.

\subsection{Batch test procedure}

To determine the short-term influence of temperature on the activity of anammox biomass cultivated at relatively low temperature $\left(23^{\circ} \mathrm{C}\right)$ a series of manometric batch activity tests in temperatures between 17 and $32^{\circ} \mathrm{C}$ were conducted according to the methodology described in the literature $[2,16]$. 
The tests were performed in a commercially available WTW OxiTop Control AN6 set-up (Figure 1.) equipped with three-necked glass bottles with a total volume of $650 \mathrm{~mL}$, closed with a manometric measurement head with pressure sensor and puncturable gas-tight septum for substrate injection and sampling. Anammox biomass sampled from the pilot SBR was used for the test, $480 \mathrm{~mL}$ of sludge was transferred to the bottle (liquid/total volume ratio of 0.75 ). The headspace and liquid volume were sparged with nitrogen to remove residual oxygen and saturate the liquid with nitrogen. The initial $\mathrm{pH}$ value was set to 7.0. The bottles were placed on magnetic stirrer located in a thermostatic chamber at a set temperature until stable conditions were reached. Then the substrates in form of a stock solution $\left(\mathrm{NH}_{4} \mathrm{Cl} 1.3 \mathrm{~g} \mathrm{~N} / \mathrm{L}, \mathrm{NaNO}_{2} 1.56 \mathrm{~g} \mathrm{~N} / \mathrm{L}, \mathrm{NaHCO}_{3} 5.46 \mathrm{~g} / \mathrm{L}\right)$ were injected (initial ammonium and nitrite concentrations 50 and $60 \mathrm{mg} \mathrm{N} / \mathrm{L}$, respectively), the initial sample taken and pressure equalized to the ambient one. Nitrogen gas production was tracked by continuous measurement and recording of the overpressure in the headspace until decrease in the process rate was observed. The final $\mathrm{pH}$ value was measured in order to check that it was in the optimal range. At the end of the test a sample was taken and analysed for TSS, VSS, ammonium, nitrite and nitrate.
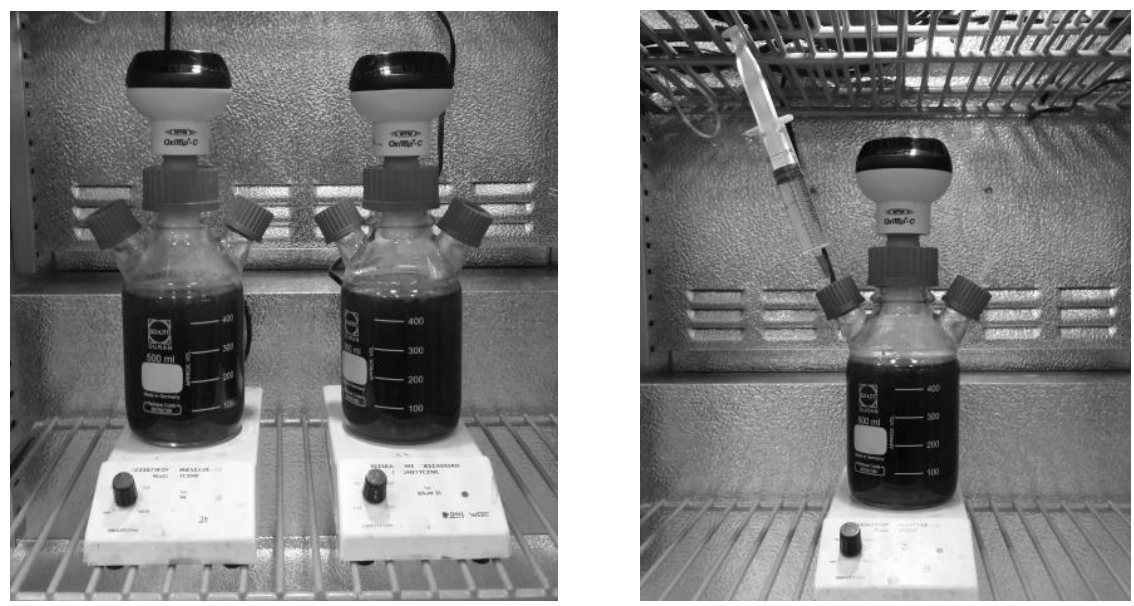

Fig. 1. Experimental set-up in a thermostatic chamber (left) and dosing of substrate (right).

\subsection{Calculations}

The overpressure increase in the headspace of the bottle during the test was used to calculate the total amount of nitrogen gas produced using the ideal gas law equation. The amount of nitrogen removed from the liquid phase was also calculated based on the initial and final concentrations of ammonium, nitrite and nitrate. The difference between both amounts was used to estimate the relative error of the method.

The nitrogen gas production rate $\left(n, \mathrm{~mol} \mathrm{~N}_{2} \cdot \mathrm{h}^{-1}\right)$ was calculated from the maximum slope of the curve of the pressure increase in the headspace along the time $\left(a, \mathrm{~Pa}^{-1}\right)$ :

$$
n=a \frac{V_{G}}{R T}
$$

where $V_{G}$ is the volume of the headspace $\left(\mathrm{m}^{3}\right), R$ the ideal gas constant $\left(8,314 \mathrm{~J} \cdot \mathrm{mol}^{-1} \mathrm{~K}^{-1}\right)$, and $T$ the temperature $(\mathrm{K})$.

The specific anammox activity $\left(S A A, \mathrm{~g} \mathrm{~N}_{2}-\mathrm{N} \mathrm{gVSS}^{-1} \mathrm{~h}^{-1}\right)$ was calculated from the gas production rate $n$ divided by the biomass content in the bottle $\left(X V_{L}, \mathrm{~g}\right.$ VSS) 


$$
S A A=\frac{n}{X V_{L}} \frac{28 g N}{m o l N_{2}}
$$

where $X$ is biomass concentration ( $\mathrm{g} \mathrm{VSS} \mathrm{m}{ }^{-3}$ ) and $V_{L}$ is the volume of the liquid phase $\left(\mathrm{m}^{3}\right)$

The activation energy $\left(E_{a}, \mathrm{~J} \mathrm{~mol}^{-1}\right)$ reflects the reaction temperature dependence and can be estimated graphically from the plot of the natural logarithm of the Arrhenius equation:

$$
\ln r=-\frac{E_{a}}{R} \cdot \frac{1}{T}+\ln A
$$

where $r$ is the specific anammox reaction rate $\left(m o l \operatorname{gVSS}^{-1} \mathrm{~d}^{-1}\right)$ and $A$ is the reaction frequency factor.

The relationship between activation energy and temperature correction factor $\theta$ (Eq. 2) is given by the equation:

$$
\theta=\exp \left(\frac{E_{a}}{R T_{1} T_{2}}\right)
$$

\subsection{Analytical methods}

Samples were filtered through standard $1.2 \mu \mathrm{m}$ glass fibre filters. Ammonium, nitrite and nitrate concentrations were determined by spectrophotometry using Hach cuvette tests.

Dissolved oxygen and $\mathrm{pH}$ were checked at the start and end of the test using Hach HQD Intellical LDO and $\mathrm{pH}$ electrodes connected to a HQ40D meter.

Biomass concentration was measured as total (TSS) and volatile suspended solids (VSS) at the end each test according to EN-872 - standard direct method for suspended solids on glass fibre filters with $1.2 \mathrm{~m}$ pore size.

\section{Results and discussion}

The short-term temperature influence on specific anammox activity (SAA) was determined in a series of batch manometric tests in the temperature range between 17 and $32^{\circ} \mathrm{C}$ conducted at least in duplicates for each temperature.

The obtained $S A A$ values as a function of process temperature are presented in Figure 2., whereas the Arrhenius plot used to estimate the activation energy is shown in Figure 3.

The observed values of $S A A$ varied between 0.39 and $1.48 \mathrm{~g} \mathrm{~N}_{2}-\mathrm{N} \mathrm{gVSS}^{-1} \mathrm{~d}^{-1}$ for the temperature of 17 and $32^{\circ} \mathrm{C}$, respectively, and they were $56 \%$ lower and $69 \%$ higher than the $S A A$ value of $0.88 \mathrm{~g} \mathrm{~N}_{2}-\mathrm{N} \mathrm{gVSS}^{-1} \mathrm{~d}^{-1}$ obtained for the temperature of $23^{\circ} \mathrm{C}$ at which the pilot-scale SBR was operated. The measured $S A A$ values fall into the typical range reported in the literature $[7,12]$.

The obtained relative errors between the amount of nitrogen gas produced based on manometric measurements and the amount of nitrogen removed from the liquid based on analytical determination were smaller than $6 \pm 10 \%$ indicating a good consistence.

The temperature correction factor $\theta=1.096$ determined for the temperature range of 17 to $32^{\circ} \mathrm{C}$ with a corresponding activation energy of $68 \mathrm{~kJ} \mathrm{~mol}^{-1}$ are in accordance with the literature which reports values of 1.065-1.1 for the temperature correction factor [7, 17] and values of 51-70 $\mathrm{kJ} \mathrm{mol}^{-1}$ for the anammox activation energy [7, 12]. 


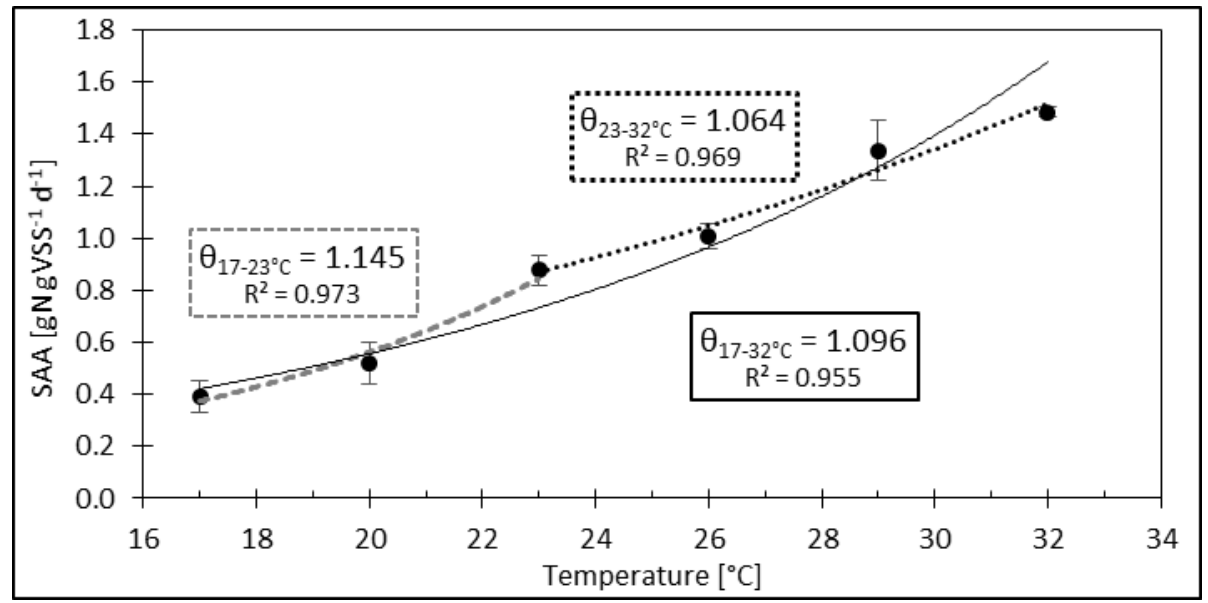

Fig. 2. Specific anammox activity as a function of temperature with the temperature correction factor $\theta$ for different temperature ranges.

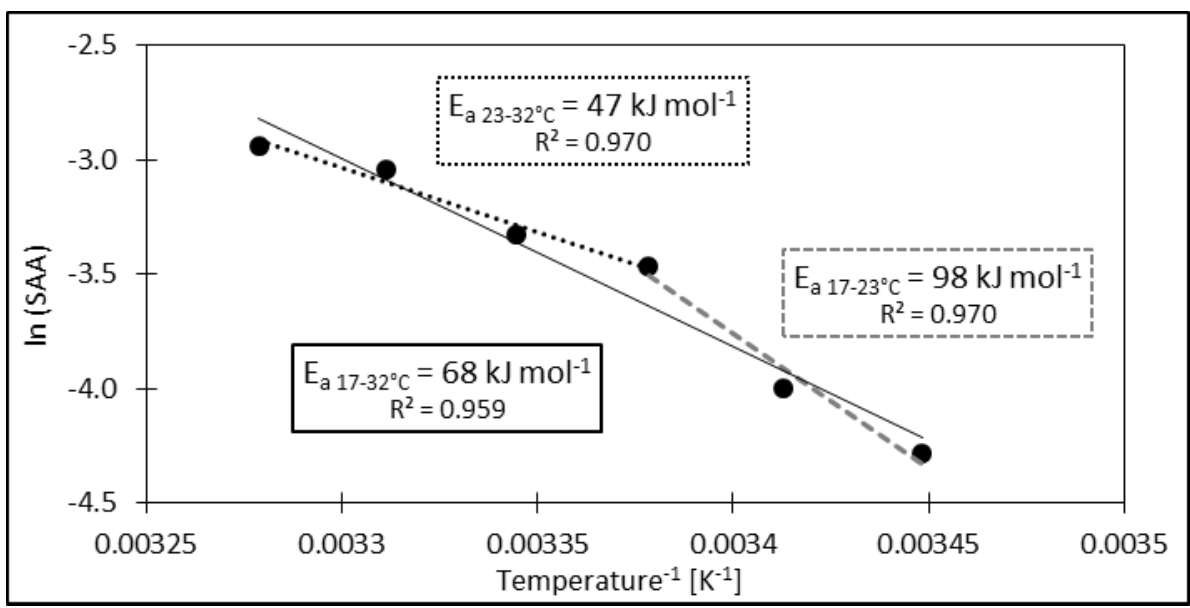

Fig. 3. Arrhenius plot for the anammox reaction with the $E_{a}$ values for different temperature ranges.

However, closer inspection reveals that actually two temperature ranges with different characteristics can be distinguished: a lower range $17-23^{\circ} \mathrm{C}$ and a higher range $23-32^{\circ} \mathrm{C}$, which is well visible at Figure 3.

For the lower temperature range $\left(17-23^{\circ} \mathrm{C}\right)$, the estimated temperature correction factor $\theta$ was equal to 1.145 with a corresponding activation energy of $98 \mathrm{~kJ} \mathrm{~mol}^{-1}$, whereas for the higher temperature range $\left(23-32^{\circ} \mathrm{C}\right)$, the estimated temperature correction factor $\theta$ was equal to 1.064 with a corresponding activation energy of $47 \mathrm{~kJ} \mathrm{~mol}^{-1}$. These values are still relatively close to the literature values mentioned above.

It is worth mentioning that the two distinguished temperature ranges were below and above the temperature of $23^{\circ} \mathrm{C}$ at which the pilot-scale SBR was operated. Considering the fact that the tests were performed without biomass acclimatization, this may suggest that a short-term temperature effect due to a shock caused by sudden temperature change may have contributed to the observed differences [18]. Lotti et al. [12] recommended an acclimatization period of $24-48 \mathrm{~h}$ to allow biomass to recover from the temperature shock effect. This, however, considerably extends the duration of the tests, but still does not account for the possible long-term temperature effect due to biomass adaptation to new conditions. 


\section{Conclusions}

Manometric batch tests allowed to characterize short-term influence of temperature in the range of $17-32^{\circ} \mathrm{C}$ on the activity of anammox biomass cultivated at relatively low temperature $\left(23^{\circ} \mathrm{C}\right)$, and estimate the temperature correction factor $\theta$ equal to 1.096 and a corresponding activation energy of $68 \mathrm{~kJ} \mathrm{~mol}^{-1}$. The potential temperature shock effect and long-term bacterial adaptation require further investigation.

Acknowledgements - The authors gratefully acknowledge co-funding from the National Centre for Research and Development (grant no. PBS2/B9/25/2014) and Municipal Water and Sewage Company Wroclaw.

\section{References}

1. J. Makinia, Mathematical modelling and computer simulation of activated sludge systems, London, New York, IWA Publishing (2010)

2. A. Dapena-Mora, I. Fernandez, J.L. Campos, A. Mosquera-Corral, R. Mendez, M.S.M. Jetten, Enzyme Microb. Tech. 40 (2007)

3. S. Lackner, E.M. Gilbert, S.E. Vlaeminck, A. Joss, H. Horn, M.C.M. van Loosdrecht, Water Res. 55 (2014)

4. T. Liu, D. Li, J. Zhang, Y. Lv, X. Quan, Biochem. Eng. J. 105 (2016)

5. J. Dosta, I. Fernandez, J.R. Vazquez-Padin , A. Mosquera-Corral, J.L. Campos, J. Mata-Alvarez, R. Mendez, J. Hazard. Mater. 154 (2008)

6. M. Strous, J.J. Heijnen, J.G. Kuenen, M.S.M. Jetten, Appl. Environ. Microbiol. 50 (1998)

7. D. Sobotka, K. Czerwionka, J. Makinia, Water Sci. Technol. 73, 10 (2016)

8. A. Daverey, P.C. Chei, K. Dutta, J.-G. Lin, Int. Biodeter. Biodegr. 102 (2015)

9. S.W.H. vanHulle, H.J.P. Vandeweyer, B.D Meesschaert, P.A. Vanrolleghem, P. Dejans, A. Dumoulin, Chem. Eng. J. 162, 1 (2010)

10. G. Cema, J. Wiszniowski, S. Zabczynski, E. Zabłocka-Godlewska, A. Raszka, J. Surmacz-Gorska, Water Sci. Technol. 55, 8/9 (2007)

11. K. Isaka, T. Sumino, S. Tsuneda, J. Biosci. Bioeng. 103, 5 (2007)

12. T. Lotti, R. Kleerebezem, M.C.M. van Loosdrecht, Biotechnol. Bioeng. 112, 1 (2015)

13. M. Strous, J.G. Kuenen, M.S.M. Jetten, Appl. Environ. Microbiol. 65 (1999)

14. J. Vazquez-Padin, I. Fernadez, M. Figueroa, A. Mosquera-Corral, J-L. Campos, R. Mendez, Bioresource Technol. 100 (2009)

15. S. Wu, A.S. Bhattacharjee, D.G. Weissbrodt, E. Morgenroth, R. Goel, Bioresource Technol. 219 (2016)

16. M.C.M. van Loosdrecht, P.H. Nielsen, C.M. Lopez-Vazquez, D. Brdjanovic, Experimental Methods in Wastewater Treatment, London, IWA Publishing (2016)

17. G. Sin, D. Kaelin, M.J. Kampschreur, I. Takacs, B. Wett, K.V. Gernaey, L. Rieger, H. Siegrist, M.C.M. van Loosdrecht, Water Sci. Technol. 58, 6 (2008)

18. J.H. Hwang, J.A. Oleszkiewicz, Water Environ. Res 79, 9 (2007) 